\title{
Fanny Bérat-Esquier, La beauté convulsive: électricité et modernité chez Baudelaire
}

\section{Ida Merello}

\section{(2) OpenEdition}

\section{Journals}

\section{Edizione digitale}

URL: http://journals.openedition.org/studifrancesi/9617

DOI: $10.4000 /$ studifrancesi.9617

ISSN: 2421-5856

\section{Editore}

Rosenberg \& Sellier

\section{Edizione cartacea}

Data di pubblicazione: 1 décembre 2007

Paginazione: 686

ISSN: 0039-2944

\section{Notizia bibliografica digitale}

Ida Merello, «Fanny Bérat-Esquier, La beauté convulsive: électricité et modernité chez Baudelaire», Studi Francesi [Online], 153 (LI | III) | 2007, online dal 30 novembre 2015, consultato il 11 janvier 2021. URL: http://journals.openedition.org/studifrancesi/9617 ; DOI: https://doi.org/10.4000/studifrancesi.9617

Questo documento è stato generato automaticamente il 11 janvier 2021.

\section{(c) $(1) \&$}

Studi Francesi è distribuita con Licenza Creative Commons Attribuzione - Non commerciale - Non opere derivate 4.0 Internazionale. 


\title{
Fanny Bérat-Esquier, La beauté convulsive: électricité et modernité chez Baudelaire
}

\author{
Ida Merello
}

\section{NOTIZIA}

FANNY BÉRAT-ESQUIER, La beauté convulsive: électricité et modernité chez Baudelaire, «Revue des Sciences Humaines», n. 281, 1/2006, pp. 95-105.

1 L'A. sottolinea come per Baudelaire l'électricité non sia un fenomeno di ordine fisico, bensì spirituale, espressione dell'energia dell'universo e assimilato all'anima. Tenta quindi di definire nei Tableaux parisiens e nello Spleen de Paris i rapporti che vengono stabiliti tra il frastuono convulso della città e della folla con l'energia elettrica. A questo proposito ricorda come già nel xviii secolo si cominciasse a studiare una comunicazione di elettricità in un gruppo e come il termine "galvanizzare" sia entrato in uso nel 1799. L'A. però vede in Baudelaire un percorso inverso (dalla moltitudine all'uno) nell'individuo elettrizzato dalla folla fino all'ebbrezza, e vi riconosce l'influenza di Poe, di cui Baudelaire stava traducendo i racconti. Lo stretto legame tra elettricità, movimento frenetico e modernità porta infine alla ricerca e definizione di una nuova bellezza, quale era peraltro già stata adombrata da Gœthe nei suoi saggi di critica d'arte, nella fattispecie a proposito del Laocoonte. 